Radchenko O. M., Guta R. R., Filipiuk A. L., Zukow W. Predictors of survival in patients with ischemic heart disease depending on therapy. Journal of Education, Health and Sport. 2020;10(2):18-26. eISSN 2391-8306. DOI http://dx.doi.org/10.12775/JEHS.2020.10.02.002

https://apcz.umk.pl/czasopisma/index.php/JEHS/article/view/JEHS.2020.10.02.002

https://zenodo.org/record $/ 3634860$

The journal has had 5 points in Ministry of Science and Higher Education parametric evaluation. § 8. 2) and § 12. 1. 2) 22.02.2019

This article is published with open access at Licensee Open Journal Systems of Nicolaus Copernicus University in Torun, Poland

Open Access. This article is distributed under the terms of the Creative Commons Attribution Noncommercial License which permits any noncommercial use, distribution, and reproduction in any medium, provided the original author (s)

(http://creativecommons.org/licenses/by-nc-sa/4.0/) which permits unrestricted, non commercial use, distribution and reproduction in any medium, provided the work is properly cited. The authors declare that there is no conflict of interests regarding the publication of this paper.

Received: 02.01.2020. Revised: 25.01.2020. Accepted: 03.02.2020.

\title{
Predictors of survival in patients with ischemic heart disease depending on therapy
}

\author{
O. M. Radchenko ${ }^{1}$, R. R. Guta ${ }^{1}$, A. L. Filipiuk ${ }^{1}$, W. Zukow ${ }^{2}$
}

1. Danylo Halytsky Lviv National Medical University, Lviv, Ukraine

2. Nicolaus Copernicus University, Torun, Poland

\begin{abstract}
The aim of the study is to assess the prognostic value of the structural and functional echocardiographic indicators in IHD patients, depending on acute coronary syndrome management (revascularization vs medical therapy), during 60 months.

Materials and methods:The total of 101 IHD patients were examined on the clinical bases of the Internal Medicine Department 2. Prior to the study. The 84 males and 17 females aged 58.6 \pm 4.2 were split into the experimental group after myocardial revascularization $(E G, n=71)$ and control group with standard medical therapy $(C G$, $\mathrm{n}=30$ ). In addition to the protocol-prescribed clinical lab tests, during five years, the dynamics of the echocardiographic cardiac parameters has been assessed. The digital data was processed by the Kaplan-Meier estimator; the 60-month cumulative survival rate (\%) was estimated and significance of the difference was assessed by Cox's F-test $(p<0.05)$.
\end{abstract}


Results and discussion.It appeared thatthe 5-year prognosis in IHD patients was unaffected by the dimensions of IVST, LVIDD and LVMMI. In 60 months after the surgery, a significantly better prognosis was observed for certain unfavourable initial conditions: enlarged $\mathrm{RV} \geq 2.5 \mathrm{~cm}(37.5 \%$ vs $30.7 \%, \mathrm{p}=0.008)$, aortic diameter $\geq 3.0 \mathrm{~cm}$ $(57.2 \%$ vs $34.3 \%, \mathrm{p}=0.02)$, enlarged LA $>4.0 \mathrm{~cm}(43.8 \%$ vs $24.7 \%, \mathrm{p}=0.046)$. In addition, revascularization was associated with better survival rates for normal LVMM ( $<250 \mathrm{~g} ; 75.8 \%$ vs $49.1 \%, \mathrm{p}=0.05)$, without the thickening of the LV walls $(66.9 \%$ vs $30.5 \%, \mathrm{p}=0.047)$ and without LV systolic dysfunction $(87.7 \%$ vs $59.9 \%, \mathrm{p}=0.046)$. An important place among the echocardiographic criteria of unfavourable prognosis belongs to LV systolic dysfunction ( $\mathrm{EF} \leq 45 \%$ ). Therefore, the experimental group patients were distributed according to the EF value, following the Ukrainian Association of Cardiology and $\mathrm{EU}$ guidelines, i.e. we singled out the so-called grey zone ( $\mathrm{EF}=45-54 \%)$, where the patients featuring LV systolic dysfunction and preserved EF belonged. The analysis of the results showed the cumulative event-free survival to be $87.4 \%$ for $\mathrm{EF}>55 \%, 14.6 \%$ for $\mathrm{EF}=45-54 \%$ and $42.9 \%$ for $\mathrm{EF}<45 \%(\mathrm{p}=0.01)$. The patients after the myocardial revascularization with $\mathrm{EF}=45-54 \%$ had a worse prognosis of event-free survival than those with LV systolic dysfunction. In the group of patients who had undergone only the medical therapy, the survival prognosis was significantly worse, which corresponded to a reduced $\mathrm{EF}\left(38.3 \%\right.$ for $\mathrm{EF}>55 \%, 15.0 \%$ for $\mathrm{EF}=45-54 \%$ and $0 \%$ for $\mathrm{EF}<45 \%$, $\mathrm{p}_{\mathrm{EG}}$ $\mathrm{CG}=0.01)$. A similar EF-based distribution was used in the study of patients with decompensated heart failure (REDINSCOR II, 2017), in which the authors revealed that the grey zone patients featured a higher risk of cardiovascular complications than patients with normal EF values did.

Conclusions.Revascularization contributed to a considerably better 60-month survival prognosis for cases featuring the enlarged right ventricle $(\geq 2.5 \mathrm{~cm})$, enlarged left atrium $(>4.0 \mathrm{~cm})$ and extended aortic root $(\geq 3.0 \mathrm{~cm})$, but with the normal left ventricular myocardial mass $(<250 \mathrm{~g})$ and without ventricular hypertrophy or systolic dysfunction. 
Key words: ejection fraction, revascularization, ischemic heart disease, survival predictors.

Introduction. In the medical literature, there are publications on the consequences of revascularization in patients with ischemic heart disease (IHD) [1]. Regardless of myocardial infarction management, structural and functional parameters of the heart change in all patients, which results in the remodelling, i.e. in hypertrophy and dilation with changes in the systolic and diastolic cardiac function [2,3]. Cardiac remodelling involves first of all increased left ventricular mass (LVM), which often causes cardiovascular complications [4,5]. As soon as in three months following myocardial revascularization, the patients manifested with the left ventricular (LV) remodelling [6,7]. Thereat, a good prognosis in them correlated with the improved LV systolic function and restored myocardial contractibility [8], and reduced LV ejection fraction is a marker of poor survival $[9,10]$. The fact that the studies aimed at the analysis of survival prognosis after myocardial revascularization are inconsiderable in number and mostly short-term $[1,8]$ adds to the importance of our research.

The aim of the study is to assess the prognostic value of the structural and functional echocardiographic indicators in IHD patients, depending on acute coronary syndrome (ACS) management (revascularization vs medical therapy), during 60 months.

Materials and methods: The total of 101 IHD patients (including ACS with ST elevation with Q (48\%), ST elevation without Q (28\%), with no ST elevation (24\%)) were examined on the clinical bases of the Internal Medicine Department 2. Prior to the study, written informed consent was obtained from all the enroleesin compliance with the Declaration of Helsinki principles. The 84 males and 17 females aged 58.6 \pm 4.2 were split into the experimental group after myocardial revascularization $(\mathrm{EG}, \mathrm{n}=71)$ and control 
group with standard medical therapy $(\mathrm{CG}, \mathrm{n}=30)$. In addition to the protocol-prescribed clinical lab tests, during five years, the dynamics of the echocardiographic cardiac parameters has been assessed, including the right ventricular diameter (RVD), left atrial diameter (LAD), LV internal diastolic diameter (LVIDD), LV posterior wall thickness (LVPWT) and interventricular septum thickness (IVST), aortic diameter and ejection fraction $(\mathrm{EF})$. The left ventricular myocardial mass (LVMM) was evaluated using the Penn Convention, and its indexed value (LVMMI) and relative wall thickness (RWT) were calculated [11]. The digital data was processed by the Kaplan-Meier estimator; the 60 -month cumulative survival rate (\%) was estimated and significance of the difference was assessed by Cox's F-test $(\mathrm{p}<0.05)$. A case of hospitalization for repeated ACS, unstable angina or chronic decompensated heart failure was considered an event.

Results and discussion. It appeared that the 5-year prognosis in IHD patients was unaffected by the dimensions of IVST, LVIDD and LVMMI (Table 1).

Table 1 - Survival rates as a function of structural and functional heart parameters

\begin{tabular}{|c|c|c|c|c|}
\hline \multicolumn{2}{|c|}{$\begin{array}{l}\text { Structural and functional heart } \\
\text { parameters }\end{array}$} & \multirow{2}{*}{\begin{tabular}{|c|}
$\begin{array}{l}\text { Experimental } \\
\text { group, \% }\end{array}$ \\
66.8 \\
\end{tabular}} & \multirow{2}{*}{$\begin{array}{l}\begin{array}{l}\text { Control } \\
\text { group, } \%\end{array} \\
52.5\end{array}$} & \multirow{2}{*}{$\begin{array}{l}\text { Survival } \\
\text { probability by } \\
\text { Cox's F-test, p } \\
>0.05 \\
\end{array}$} \\
\hline & $\leq 2.4 \mathrm{~cm}$ & & & \\
\hline Right ventricle & $\geq 2.5 \mathrm{~cm}$ & 37.5 & 30.7 & 0.008 \\
\hline \multirow{2}{*}{ Aorta } & $\leq 2.9 \mathrm{~cm}$ & 69.2 & 77.8 & $>0.05$ \\
\hline & $\geq 3.0 \mathrm{~cm}$ & 57.2 & 34.3 & 0.02 \\
\hline \multirow{2}{*}{ Left atrium } & $\leq 4.0 \mathrm{~cm}$ & 76.0 & 57.1 & $>0.05$ \\
\hline & $>4.0 \mathrm{~cm}$ & 43.8 & 24.7 & 0.046 \\
\hline \multirow{2}{*}{$\begin{array}{l}\text { Left ventricular internal } \\
\text { diastolic diameter }\end{array}$} & $<5.7 \mathrm{~cm}$ & 65.7 & 54.3 & $>0.05$ \\
\hline & $\geq 5.7 \mathrm{~cm}$ & 35.1 & 0.0 & $>0.05$ \\
\hline \multirow{2}{*}{$\begin{array}{l}\text { Interventricular septum } \\
\text { thickness }\end{array}$} & $<1.1 \mathrm{~cm}$ & 68.3 & 24.2 & $>0.05$ \\
\hline & $\geq 1.1 \mathrm{~cm}$ & 54.6 & 52.9 & $>0.05$ \\
\hline \multirow{2}{*}{$\begin{array}{l}\text { Left ventricular posterior } \\
\text { wall thickness }\end{array}$} & $<1.1 \mathrm{~cm}$ & 66.9 & 30.5 & 0.047 \\
\hline & $\geq 1.1 \mathrm{~cm}$ & 55.4 & 57.6 & $>0.05$ \\
\hline \multirow{2}{*}{ Ejection fraction } & $>50 \%$ & 87.7 & 59.9 & 0.046 \\
\hline & $\leq 50 \%$ & 24.6 & 37.8 & $>0.05$ \\
\hline \multirow{2}{*}{$\begin{array}{l}\text { Left ventricular myocardial } \\
\text { mass }\end{array}$} & $<250 \mathrm{~g}$ & 75.8 & 49.1 & 0.05 \\
\hline & $\geq 250 \mathrm{~g}$ & 40.1 & 31.8 & $>0.05$ \\
\hline \multirow{2}{*}{$\begin{array}{l}\text { Left ventricular myocardial } \\
\text { mass index }\end{array}$} & $<115 \mathrm{~cm} / \mathrm{g}$ & 60.3 & 37.5 & $>0.05$ \\
\hline & $\geq 115 \mathrm{~cm} / \mathrm{g}$ & 44.6 & 53.6 & $>0.05$ \\
\hline \multirow{2}{*}{$\begin{array}{l}\text { Left ventricular relative } \\
\text { wall thickness }\end{array}$} & $<0.42$ & 40.1 & 14.9 & 0.05 \\
\hline & $\geq 0.42$ & 66.7 & 67.1 & $>0.05$ \\
\hline
\end{tabular}


In 60 months after the surgery, a significantly better prognosis was observed for certain unfavourable initial conditions: enlarged $\mathrm{RV} \geq 2.5 \mathrm{~cm}(37.5 \%$ vs $30.7 \%, \mathrm{p}=0.008)$ (Fig. 1A), aortic diameter $\geq 3.0 \mathrm{~cm}(57.2 \%$ vs $34.3 \%, \mathrm{p}=0.02)$, enlarged LA $>4.0 \mathrm{~cm}$ (43.8\% vs $24.7 \%, \mathrm{p}=0.046)$ (Fig. 1B).

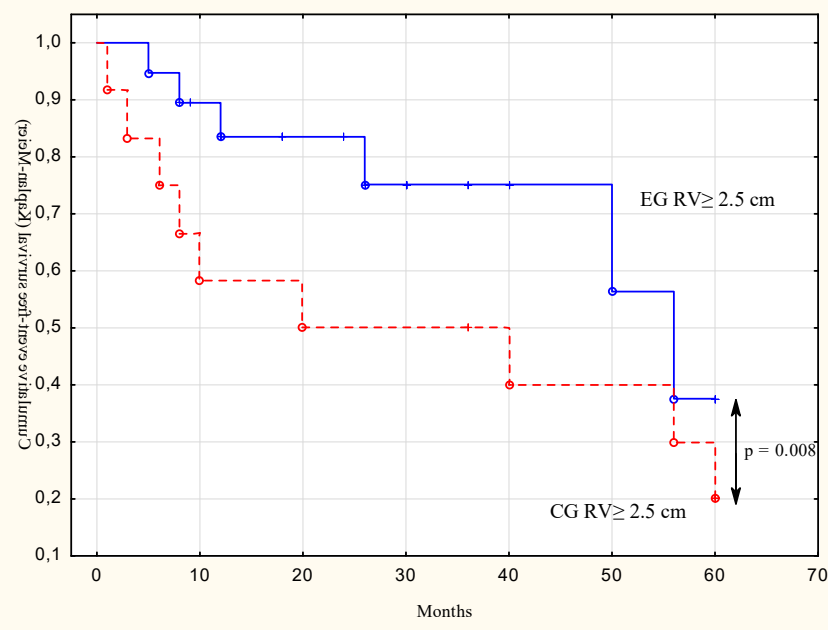

A

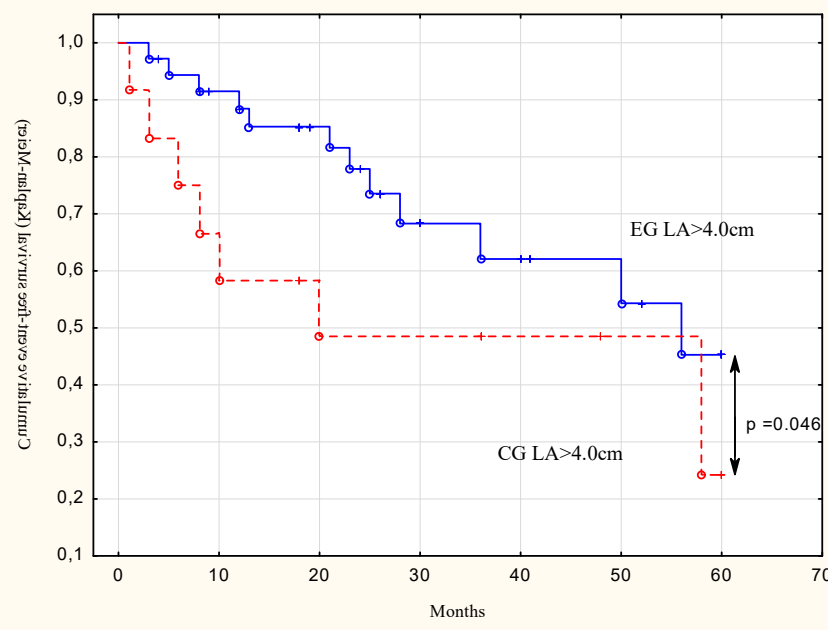

B

Fig. 1. Survival of patients with enlarged right ventricle (A) and enlarged left atrium (B) depending on management

In addition, revascularization was associated with better survival rates for normal LVMM ( $<250 \mathrm{~g} ; 75.8 \%$ vs $49.1 \%$, p=0.05) (Fig.2), without the thickening of the LV walls $(66.9 \%$ vs $30.5 \%, \mathrm{p}=0.047)$ and without LV systolic dysfunction $(87.7 \%$ vs $59.9 \%$, $\mathrm{p}=0.046)$.

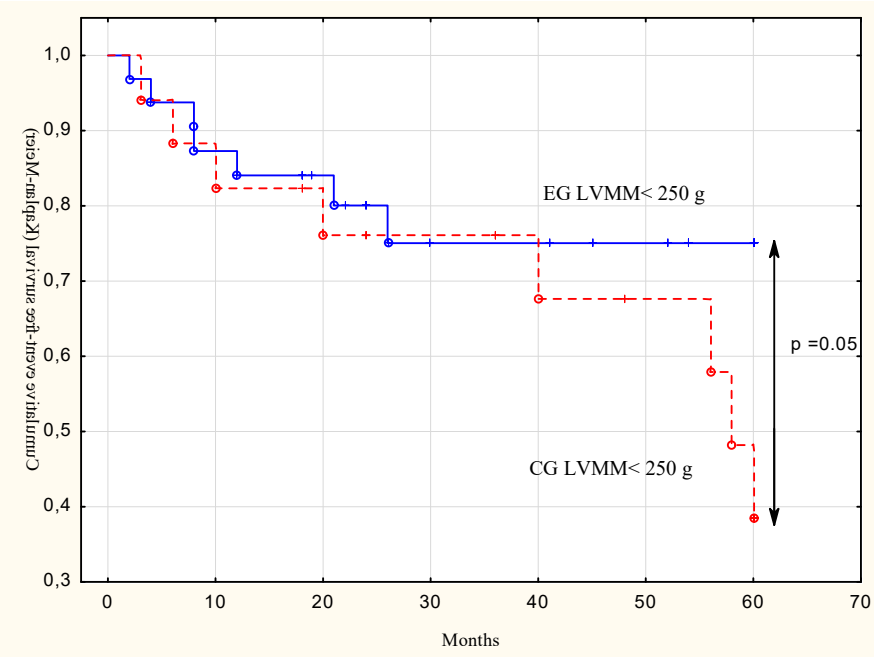

Fig. 2. Survival in patients with the left ventricular myocardial mass below $250 \mathrm{~g}$, depending on management 
According to the literature data, a treatment method not taken into account, the echocardiographic predictors of cardiovascular events in IHD patients include the enlarged LA, dilated LV and reduced EF $[9,10,12,13]$. For instance, for the case of enlarged LV and low EF, a three-year survival in IHD patients after the myocardial revascularization was $44.6 \%$, whereas in the group where only medical therapy was administered it was $22 \%$ $[6,13]$, and for the cases with enlarged LV the patients' survival was $65 \%$ versus $81 \%$ [12]. Our data show that there was no significant difference between the survival rates of patients who underwent a conservative treatment and those after surgeries for different values of LVIDD, LV wall thickness and EF below 50\%. On the contrary, we found that myocardial revascularization promotes a better prognosis even if there are already unfavourable structural changes (Table 1, Fig.1A, B).

An important place among the echocardiographic criteria of unfavourable prognosis belongs to LV systolic dysfunction $(\mathrm{EF} \leq 45 \%)[9,10]$. Therefore, the experimental group patients were distributed according to the EF value, following the Ukrainian Association of Cardiology and EU guidelines [11], i.e. we singled out the so-called grey zone ( $E F=45-$ 54\%), where the patients featuring LV systolic dysfunction and preserved EF belonged [14]. The analysis of the results showed the cumulative event-free survival to be $87.4 \%$ for $\mathrm{EF}>55 \%, 14.6 \%$ for $\mathrm{EF}=45-54 \%$ and $42.9 \%$ for $\mathrm{EF}<45 \%(\mathrm{p}=0.01)($ Fig. 3$)$.

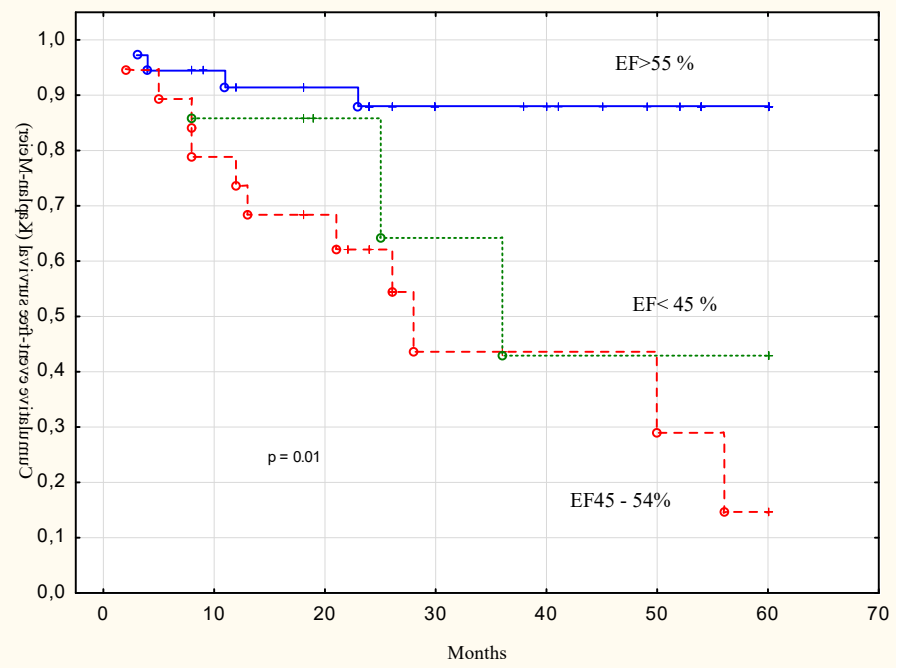

Fig. 3. Survival of patients after myocardial revascularization depending on ejection fraction

The patients after the myocardial revascularization with $\mathrm{EF}=45-54 \%$ had a worse 
prognosis of event-free survival than those with LV systolic dysfunction. In the group of patients who had undergone only the medical therapy, the survival prognosis was significantly worse, which corresponded to a reduced $\mathrm{EF}$ (38.3\% for EF $>55 \%, 15.0 \%$ for $\mathrm{EF}=45-54 \%$ and $0 \%$ for $\mathrm{EF}<45 \%$, $\left.\mathrm{p}_{\mathrm{EG}-\mathrm{CG}}=0.01\right)$. A similar EF-based distribution was used in the study of patients with decompensated heart failure (REDINSCOR II, 2017) [15], in which the authors revealed that the grey zone patients featured a higher risk of cardiovascular complications than patients with normal EF values did.

Conclusions. Revascularization contributed to a considerably better 60-month survival prognosis for cases featuring the enlarged right ventricle $(\geq 2.5 \mathrm{~cm})$, enlarged left atrium $(>4.0 \mathrm{~cm})$ and extended aortic root $(\geq 3.0 \mathrm{~cm})$, but with the normal left ventricular myocardial mass $(<250 \mathrm{~g})$ and without ventricular hypertrophy or systolic dysfunction.

The study can be extended to explore the reasons behind the worsening of the prognosis in IHD patients whose left ventricular ejection fraction falls within the grey zone.

Conflict of interest. The authors declare that there is no conflict of interest regarding the publication of this article.

\section{References}

1. Filsoufi F, Jouan $\mathrm{J}$ et al. Results and predictors of early and late outcome of coronary artery bypass graft surgery in patients with ejection fraction less than $20 \%$. Arch. Cardiovasc. Dis. 2008;101(9):547-556.

2. BaxJJ,Schinkel AFL, Boersma E et al. Extensive left ventricular remodeling does not allow viable myocardium to improve in left ventricular ejection fraction after revascularization and is associated with worse long-term prognosis. Circulation. 2004;110:18-22.

3. Denesyuk VI, Denesyuk OV, Muzyka NO. Remodelyuvannya livoho shlunochka u khvorykh na stabil'hu stenokardiyu, uskladnenu sertsevoyu nedostatnistyu, zi znyzhenoyu i zberezhenoyu fraktsiyeyu vykydu [Left ventricular remodeling in patients with angina 
pectoris, complicated by heart failure, with reduced and preserved ejection fraction]. Lviv Clinical Bulletin. 2016; 2(14)-3(15):8-13.

4. Lieb W, Gona P, Larson MG et al. The natural history of left ventricular geometry in the community: clinical correlates and prognostic significance of change in LV geometric pattern. JACC Cardiovasc Imaging. 2014;7(9):870-878.

5. Nadruz W. Myocardial remodeling in hypertension. J.Hum.Hypertens.2015; 29(1):1-6.

6. $\mathrm{Xu} \mathrm{L}$, Huang $\mathrm{X}$, Ma $\mathrm{J}$ et al. Value of three-dimensional strain parameters for predicting left ventricular remodeling after ST-elevation myocardial infarction. Int. J. Cardiovasc Imaging. 2017;33(5):663-673.

7. Sekaran NK, Crowley AL, de Souza FR et al.The Role for Cardiovascular Remodeling in Cardiovascular Outcomes. 2017;19(5):23.

8. Abdelgawwad IM, Al Hawary AA, Kamal HM et al. Prediction of left ventricular contractile recovery using tissue Doppler strain and strain rate measurements at rest in patients undergoing percutaneous coronary intervention. Int. J. Cardiovasc Imaging. 2017;33(5):643-651.

9. Merhel TV. Stan skorotlyvoyi zdatnosti livoho shlunochka u khvorykh pislya perenesenoho infarktu miokarda $\mathrm{u}$ protsesi vidnovnoho likuvannya [Left Ventricular Contractile State in Patients Undergoing Rehabilitation after Myocardial Infarction]. Halych Medicinal Bulletin. 2015; 22(1):145-147.

10. Yakovleva LM, Peremot YAO. Chynnyky, shchovplyvayut' na viddaleny yprohnoz u khvorykh na ishemichnu khvorobu sertsya, yaki perenesly aortokoronarne shuntuvannya [Factors affecting long-term prognosis in patients with coronary artery disease who underwent coronary artery bypass grafting].Emergency medicine. 2013; 7(54):128-132.

11. Lang RM, Badano LP, Mor-Avi V et al. Recommendations for cardiac chamber quantification by echocardiography in adults: an update from the American Society of Echocardiography and the European Association of Cardiovascular Imaging. Journal of 
the American Society of Echocardiography. 2015; 28(1): 1-39.

12. Filipyuk AL. Strukturno-funktsional'nyy stan sertsya u khvorykh na khronichnu ishemichnu khvorobu sertsya $\mathrm{z}$ nadvahoyu ta ozhyrinnyam: predyktory vyzhyvannya [Structural-Functional Cardiac Parameters in Patients with Chronic Ischemic Heart Disease Combined with Overweight and Obesity: Predictors of Survival]. Ukrainian journal of medicine, biology and sports. 2016; 1(1): 99-102.

13. Zelenchuk OV, Todurov BM. Khirurhichne likuvannya patsiyentiv z ishemichnoyu khvoroboyu sertsya ta vyrazhenoyu systolichnoyu dysfunktsiyeyu livoho shlunochka [Surgical treatment of the ischemic heart disease with severe left ventricular systolic dysfunction].Cardiac surgery and interventional cardiology. 2015;2: 7-15.

14. Yepanchintseva OA, Zharinov OY, Mikhalyev KO, Todurov BM. Dysfunktsiya livoho shlunochka pered planovoyu khirurhichnoyu revaskulyaryzatsiyeyu. Osoblyvosti "siroyi zony" [Left ventricular dysfunction before planned surgical revascularization. Features of the «grey area»].Ukrainian Cardiology Journal. 2018;1: 29-44.

15. Gómez-Otero I, Ferrero-Gregori A, Varela RománA et al. Mid-range ejection fraction does not permit risk stratification among patients hospitalized for heart failure. Rev. Esp. Cardiol. (Engl Ed). 2017; 70 (5): 338-346. 